\title{
Effect of Antihypertensive Drug Therapy on the Blood Pressure Control among Hypertensive Patients Attending Campus' Teaching Hospital of Lome, Togo, West Africa
}

\author{
Yao Potchoo $^{1}$, Edem Goe-Akue ${ }^{1}$, Findibe Damorou ${ }^{1}$, Barima Massoka ${ }^{2}$, Datouda Redah ${ }^{1}$, \\ Innocent P. Guissou ${ }^{3}$ \\ ${ }^{1}$ University of Lome, Mixed Faculty of Medicine and Pharmacy, Lome, Togo; ${ }^{2}$ University of Lome, School of Medical Assistants, \\ Lome, Togo; ${ }^{3}$ University of Ouagadougou, UFR/SOH, Laboratory of Pharmacology/Toxicology, Ouagadougou, Burkina Faso. \\ Email: ypotchoo@hotmail.com
}

Received January $17^{\text {th }}, 2012$; revised February $24^{\text {th }}, 2012$; accepted March $6^{\text {th }}, 2012$

\begin{abstract}
High blood pressure (HBP) is a health problem world-wide. In Togo, that affection constitutes a more and more preoccupying cause of morbidity and mortality. This study is a prospective one which intended to identify the antihypertensive regimens prescribed and evaluate their effect on patients' blood pressure (BP) control. Out of the 204 patients enrolled (mean: $55.01 \pm 12.55$ years; sex ratio: 1.3), 112/176 placed on antihypertensive therapy have controlled their BP (38.39\% outpatients vs $61.61 \%$ inpatients). Related to the sex factor, we didn't observe any significant difference in the BP control. Whereas, the mean median value of BP reduction of outpatients $(30.00 / 15.00 \mathrm{mmHg})(\mathrm{p}=0.001)$ was half lower than that of inpatients $(60.00 / 30.00 \mathrm{mmHg}(\mathrm{p}=0.004))$. Thirty five outpatients $(81.40 \%)$ vs 64 inpatients (92.75\%) were placed on combination therapy. The bitherapy was prescribed to 23 outpatients $(53.49 \%)$ against 27 inpatients (39.13\%) while the quadritherapy and more than 4 drugs combination were prescribed exclusively to inpatients $(20.29 \%, n=14)$. That quadritherapy induced a significant mean reduction of inpatients' SBP compared to monotherapy $(\mathrm{p}=0.043)$ and to bitherapy $(\mathrm{p}=0.004)$. The favorite combinations were $\mathrm{D}+\mathrm{CCA}, \mathrm{D}+\mathrm{ACEI}, \mathrm{D}+\mathrm{CCA}+\mathrm{ACEI}$ and $\mathrm{D}+\mathrm{CCA}+\mathrm{ACEI}+\mathrm{CAAD}$ of which the quadruple therapy showed a significant inpatients' DBP control $(\mathrm{p}=0.015)$ compared to D + CCA combination. The combinations including at least one diuretic induced a significant difference between outpatients (median value: 30.000/10.000 mmHg) $(\mathrm{p}<0.001)$ and inpatients (median value: $60.000 \mathrm{mmHg} / 30$ $\mathrm{mmHg})(\mathrm{p}<0.001)$. The first-line molecules and fixe combinations prescribed in decreasing frequency were among others: hydrochlorothiazide + captopril, nicardipine, $\alpha$ methyldopa for outpatients; furosemide, nicardipine, captopril, $\alpha$ methyldopa, hydrochlorothiazide + captopril for inpatients. Diuretics, CCAs and ACEIs were the 3 favorite pharmacological groups for essential hypertension management in our African resource limited context. Combined to CAAD, they represented the best quadruple combination among inpatients having showed a significant difference in DBP control compared to D + CCA combination.
\end{abstract}

Keywords: Antihypertensive Drugs; Ambulatory Patients; Hospitalized Patients; Blood Pressure Control; Prescription; Monotherapy; Bitherapy; Tritherapy; Quadritherapy; CHU-Campus; Togo; West Africa

\section{Introduction}

Essential high blood pressure (HBP) is a public health problem world-wide due to its prevalence, its asymptomatic character (at the initial stage of the disease), its chronicity, its cerebro vascular and cardio-vascular [1,2], renal complications and its weight in the expenses of health. Many factors among which the low level of adherence for therapeutic schedules, ignorance, poverty [3-5], the role of health staff $[6,7]$ and the complexity of anti hypertensive therapy [8] explain the high rate of the resistance to the treatment.
In Togo, that affection is a more and more preoccupying with prevalences from $22 \%$ [9] to $74.29 \%$ in patients over 50 years [10] and morbidity and mortality rate of about $59.5 \%$ and $11 \%$ respectively among people over 50 years [10]. Regarding its high morbi-mortality and its complications which take place all the more quickly for lack of an adequate management, an early treatment proves to be necessary. At $90 \%$ - 95\% of cases [11], the HBP does not have any apparent cause, hence the name essential high blood pressure which needs a long-term treatment. Among the predilection treatments, antihypertensive drugs, one of the most used therapeutic groups 
[12], occupies the best place. However, there are various pharmacological groups with different target, essentially central nervous system, cardiovascular and renal system. Those drugs are used either in monotherapy or most often in combination of 2, 3, 4 drugs belonging to different pharmacological groups hence the difficulty of the choice for a better synergy and a lesser risks. The data of the literature estimate that the blood pressure (BP) of $1 / 3$ of patients is controlled by monotherapy, $1 / 3$ by bitherapy and the remaining $1 / 3$ by an antihypertensive drugs number superior or equal to 3 [8]. The HBP pharmacotherapy associated or not with hygieno-dietetic measures, aims at the reduction of BP, cardiovascular risks (myocardial infarction, cerebro-vascular accident and stroke) [13-15] without adversely affecting patients' quality of life. It requires a high level of adherence.

That prospective study, the first of its type in Togo and which has very few data in sub-Saharan Africa, intends to identify the antihypertensive drugs as well as the combinations of interest which induced the BP control among patients admitted in CHU-Campus Teaching Hospital of Lomé; to evaluate the role of sex factor and the patients' ambulatory or hospitalized status, to compare the effect of the combinations of different pharmacological groups of antihypertensive drugs on patients' BP control. The study findings would allow to have some pre-requisites for the elaboration of interventions for antihypertensive drugs use and the improvement of essential HBP management.

\section{Method}

\subsection{Eligible Patients}

The criteria of enrolment were all patient having consulted or having been referred or hospitalized at the service of cardiology of Campus' Teaching hospital and among whose the diagnosis of HBP has been made (BP higher than the limits defined by the Wold Health Organization (WHO)): $140 \mathrm{mmHg}$ for the systolic blood pressure (SBP) and $90 \mathrm{mmHg}$ for the diastolic blood pressure (DBP); patients were submitted to a check-up and then placed on an antihypertensive drug therapy.

Patients with irregular follow up visits, those whose data collected was incomplete or whose adherence was poor and those that claimed to take in addition to the medicinal treatment a traditional remedy were excluded from the study.

\subsection{Material}

To measure the parameters of interest (blood pressure, weight, size) we used:

-Spengler mercury Sphygmomanometer provided with an armband for adult of $12 \mathrm{~cm}$ large,

\author{
-Spengler Stethoscope, \\ -Height, \\ -SECA Scales with maximum load of $150 \mathrm{~kg}$.
}

\subsection{Data Collection Method and Variable of Interest}

The present survey was prospective covering a period of one year from February 2001 to January 2002. It was conducted among the outpatients and inpatients attending the service of cardiology of Campus' Teaching Hospital for hypertension conditions. A card of questionnaire allowed us to collect the information concerning the age, the sex, the hospitalized or ambulatory status, the level of the blood pressure before placing them on antihypertensive therapy, the antihypertensive therapy regimens applied to patients and then the level of the blood pressure after placing the patients on single drug therapy or combination therapy.

The blood pressure was measured using the auscultatory method. The conditions of measurement were the rest condition, the quietness and without emotion.

The status of hypertension control was classified as controlled and uncontrolled hypertension using the limits defined previously. The mean difference between baseline SBP/DBP and that obtained after placing patients on antihypertensive therapy was calculated. These mean differences were used to compare treated groups.

\subsection{Study Limits}

The patients' age, the ethnic and religion considerations, the factors of risk (obesity, diabetes, lipidic disorder, sedentary lifestyle, stress and alcoholism) as well as the associated pathologies and their number in a same patient have not been taken into consideration in the analysis of the results. The survey was not interested in the undesirable events that could occur in the course of the treatments and the rate of patients' adherence to antihypertensive drug therapy.

Given that the Ethic Committee was not available at the period of the study, the Ministry of the Health authorized the survey.

\subsection{Statistical Analyses}

The treated groups were compared using ANOVA method (Sigma Stat32 software; Jandal Corp, San Rafael, $\mathrm{CA}$ ): Student t-test was used for the sex factor and the ambulatory or the hospitalized status on BP control; the $B P$ reduction induced by antihypertensive regimens was compared using ANOVA one way for SBP control; one way ANOVA was associated with Kruskal-Wallis on Ranks for DBP control (ambulatory patients); Bonferroni t-test (multiple comparison procedures) for SBP control, 
Kruskal-Wallis on Ranks and Dunn's method (multiple comparison procedures) for DBP control (hospitalized patients).

The control of the BP by pharmacological class combination of antihypertensive drugs was compared using: one way ANOVA for SBP and one way ANOVA/ Kruskal-Wallis on Ranks for DBP (ambulatory patients); one way ANOVA for SBP and one way ANOVA/ Bonferroni t-test for DBP (hospitalized patients).

Student t-test and Mann-Whitney Rank Sum Test were used to assess the effect of combination therapy including at least one diuretic on mean reduction of SBP/DBP among ambulatory and hospitalized patients.

The difference between the treated groups was considered to be significant if $\mathrm{p}<0.05$.

\section{Results}

\subsection{Epidemiological Aspect}

Of the 204 patients included in the study, 176 were placed on antihypertensive drug therapy; among them 99 were male (56.25\%) while 77 females (43.75\%) with a sex ratio of 1.3. The average age was $55.01 \pm 12.55$ years (29 to 87 years). The pattern of treatment was ambulatory for 82 patients (46.59\%) and hospitalized for 94 patients (53.41\%); 23 case notes were not used due to incompleteness. Five patients were placed on only dietary sodium restriction or anxiolytic drugs.

\subsection{Blood Pressure Control among Ambulatory Patients}

\subsubsection{Sex and Ambulatory Status and Blood Pressure Control}

The mean and median values of both SBP/DBP reductions under antihypertensive treatment were 44.21/10.00 $\mathrm{mmHg}$ for the male and 33.99/15.00 $\mathrm{mmHg}$ for the female.

Of the 112 patients who controlled their BP under hypertensive treatment, 43 (38.39\%) received an ambulatory treatment. The mean median value of both SBP/DBP reductions due to that treatment was $30.00 / 15.00 \mathrm{mmHg}$ (Table 1).

\subsubsection{Antihypertensive Therapy on Blood Pressure Control among Ambulatory Patients}

Thirty five outpatients $(81.40 \%)$ were placed on combination therapy of whom 23 were on bitherapy (53.49\%) and 12 on tritherapy (27.91\%). Eight (18.60\%) were on monotherapy (Table 2).

These tree antihypertensive regimens were not different regarding the mean and median values of both SBP/DBP reductions (Table 3).

The monotherapy made of calcium channel antago-
Table 1. Distribution of patients whose BP was controlled according to the ambulatory or hospitalized status and assessment of the effect of this status on the mean SBP/DBP reductions.

\begin{tabular}{cccccc}
\hline & & \multicolumn{2}{c}{$\begin{array}{c}\text { SBP reduction } \\
(\mathrm{mmHg})\end{array}$} & \multicolumn{2}{c}{$\begin{array}{c}\text { DBP reduction } \\
(\mathrm{mmHg})\end{array}$} \\
\cline { 3 - 6 } Treated groups & $\mathrm{n}$ & $\begin{array}{c}\text { Median } \\
\text { value }\end{array}$ & $\mathrm{p}$ & $\begin{array}{c}\text { Median } \\
\text { value }\end{array}$ & $\mathrm{p}$ \\
\hline $\begin{array}{c}\text { Ambulatory } \\
\text { patients }\end{array}$ & 43 & 30.00 & & 15.00 & \\
$\begin{array}{c}\text { Hospitalized } \\
\text { patients }\end{array}$ & 69 & 60.00 & 0.001 & 30.00 & 0.004 \\
\hline
\end{tabular}

SBP: systolic blood pressure; DBP: diastolic blood pressure; n: number of ambulatory and hospitalized patients with controlled BP.

Table 2. Distribution of patients whose BP was controlled according to antihypertensive regimens prescribed among ambulatory or hospitalized patients.

\begin{tabular}{ccccc}
\hline \multirow{2}{*}{ Antihypertensive regimens } & \multicolumn{2}{c}{ Ambulatory } & \multicolumn{2}{c}{ Hospitalized } \\
\cline { 2 - 5 } & $\mathrm{n}$ & $\%$ & $\mathrm{n}$ & $\%$ \\
\hline Bitherapy & 23 & 53.49 & 27 & 39.13 \\
Tritherapy & 12 & 27.91 & 23 & 33.33 \\
Monotherapy & 8 & 18.60 & 5 & 7.25 \\
Quadritherapy & - & - & 13 & 18.84 \\
$>4$ antihypertensive drugs & - & - & 1 & 1.45 \\
combination & & & & 100.00 \\
Total & 43 & 100.00 & 69 & \\
\hline
\end{tabular}

n: number of ambulatory and hospitalized patients with controlled BP.

Table 3. Comparison of the effect of antihypertensive regimens prescribed on the mean reduction of SBP/DBP among ambulatory patients.

\begin{tabular}{cllll}
\hline \multirow{2}{*}{$\begin{array}{c}\text { Antihypertensive } \\
\text { regimens }\end{array}$} & \multicolumn{2}{c}{$\begin{array}{c}\text { SBP reduction } \\
(\mathrm{mmHg})\end{array}$} & \multicolumn{2}{c}{$\begin{array}{c}\text { DBP reduction } \\
(\mathrm{mmHg})\end{array}$} \\
\cline { 2 - 5 } & $\begin{array}{l}\text { Mean } \\
\text { value }\end{array}$ & $\mathrm{p}$ & $\begin{array}{c}\text { Median } \\
\text { value }\end{array}$ & $\mathrm{p}$ \\
\hline Bitherapy $(\mathrm{n}=23)$ & 34.13 & & 10.00 & \\
Tritherapy $(\mathrm{n}=12)$ & 38.33 & 0.295 & 17.50 & 0.576 \\
Monotherapy $(\mathrm{n}=8)$ & 48.75 & & 20.00 & \\
\hline
\end{tabular}

$\mathrm{n}$ : number of ambulatory patients with controlled BP.

nists (CCA) and the antihypertensive class combinations such as diuretic (D) + CCA, D + angiotensin converting enzyme inhibitor (ACEI), D + CCA + ACEI were comparable in term of the mean reduction of both SBP ( $\mathrm{p}=$ $0.079)$ and DBP $(p=0.137)$ (Table 4).

Patients placed on combination therapy including at least one diuretic were 34/35 (97.14\%). The median value of SBP/DBP lowering was 30.00/10.00 $\mathrm{mmHg}(\mathrm{p}<$ 0.001) (Table 8).

The molecules and fixe combinations which were preferentially prescribed in decreasing frequency were: hydrochlorothiazide + captopril, nicardipine, $\alpha$ methyldopa, furosemide/indapamide and bendroflumethiazine + re- 
Table 4. Comparison of the effect of antihypertensive class combinations on the mean reduction of SBP/DBP among ambulatory patients.

\begin{tabular}{cllll}
\hline \multirow{2}{*}{$\begin{array}{c}\text { Antihypertensive class } \\
\text { combinations }\end{array}$} & \multicolumn{2}{c}{$\begin{array}{c}\text { SBP reduction } \\
(\mathrm{mmHg})\end{array}$} & \multicolumn{2}{c}{$\begin{array}{c}\text { DBP reduction } \\
(\mathrm{mmHg})\end{array}$} \\
\cline { 2 - 5 } & $\begin{array}{c}\text { Mean } \\
\text { value }\end{array}$ & $\mathrm{p}$ & $\begin{array}{c}\text { Median } \\
\text { value }\end{array}$ & $\mathrm{p}$ \\
\hline CCA $(\mathrm{n}=4)$ & 61.250 & & 20.000 & \\
D + CCA $(\mathrm{n}=4)$ & 45.000 & 20.000 & \\
D + ACEI $(\mathrm{n}=13)$ & 29.615 & 0.079 & 10.000 & 0.137 \\
D +CCA + ACEI $(\mathrm{n}=3)$ & 21.665 & & 10.000 & \\
Others $(\mathrm{n}=19)$ & 40.000 & & 20.000 & \\
\hline
\end{tabular}

$\mathrm{n}$ : number of ambulatory patients with controlled BP.

serpine/spironolactone + altizide.

\subsection{Blood Pressure Control among Hospitalized Patients}

\subsubsection{Sex and Hospitalized Status and Blood Pressure Control}

The median and mean values of both SBP/DBP reductions under antihypertensive treatment were 60.00/33.16 $\mathrm{mmHg}$ for the male and $60.00 / 30.97 \mathrm{mmHg}$ for the female.

Of the 112 patients who controlled their BP, 69 (61.61\%) were hospitalized. Among them the antihypertensive treatment induced both SBP/DBP reductions expressed as the mean median value of $60.00 / 30.00 \mathrm{mmHg}$ (Table 1).

\subsubsection{Antihypertensive Therapy on Blood Pressure Control among Hospitalized Patients}

Of the 69 inpatients, 27 were placed on bitherapy (39.13\%), 23 on tritherapy (33.33\%), 14 on quadritherapy $(\mathrm{n}=13)$ and $>4$ antihypertensive drugs combination (20.29\%) and 5 benefited from monotherapy (Table 2). The combination therapy was applied to 64 patients (92.75\%).

The difference in SBP mean reduction was $43.23 \mathrm{mmHg}$ between quadritherapy and monotherapy $(\mathrm{p}=0.043)$, $35.89 \mathrm{mmHg}$ between quadritherapy and bitherapy $(\mathrm{p}=$ $0.004)$ and $26.18 \mathrm{mmHg}$ between quadritherapy and tritherapy ( $=0.079$ ) (Table 5). The difference of ranks of DBP mean reduction between the four regimens were in Table 5. The median values of DBP mean reduction were: $10 \mathrm{mmHg}$ (monotherapy), $20 \mathrm{mmHg}$ (bitherapy), $30 \mathrm{mmHg}$ (tritherapy) and $40 \mathrm{mmHg}$ (quadrictherapy) (p $=0.023$ ).

The combinations including D + CCA, D + ACEI, D + CCA + ACEI and D + CCA + ACEI + CAAD induced mean values of SBP reduction represented in Table 6 (p $=0.121$ ). The quadruple combination exerted a DBP mean reduction of $38.39 \mathrm{mmHg}$ (difference of ranks) compared to D + CCA-based combination ( $\mathrm{p}=0.015)$. All other combinations were comparable concerning the
Table 5. Comparison of the effect of antihypertensive regimens prescribed on the mean reduction of SBP/DBP among hospitalized patients.

\begin{tabular}{|c|c|c|c|c|}
\hline \multirow{2}{*}{$\begin{array}{l}\text { Antihypertensive } \\
\text { regimens prescribed }\end{array}$} & \multicolumn{2}{|c|}{$\begin{array}{l}\text { SBP reduction } \\
(\mathrm{mmHg})\end{array}$} & \multicolumn{2}{|c|}{$\begin{array}{l}\text { DBP reduction } \\
(\mathrm{mmHg})\end{array}$} \\
\hline & $\begin{array}{l}\text { Difference } \\
\text { of means }\end{array}$ & $\mathrm{p}$ & $\begin{array}{l}\text { Difference } \\
\text { of ranks }\end{array}$ & $\mathrm{p}$ \\
\hline $\begin{array}{l}\text { Quadritherapy }(\mathrm{n}=13) \\
\text { vs Monotherapy }(\mathrm{n}=5)\end{array}$ & 43.231 & 0.043 & 26.462 & NS \\
\hline $\begin{array}{l}\text { Quadritherapy }(\mathrm{n}=13) \\
\text { vs Bitherapy }(\mathrm{n}=27)\end{array}$ & 35.897 & 0.004 & 17.165 & NS \\
\hline $\begin{array}{l}\text { Quadritherapy }(n=13) \\
\text { vs Tritherapy }(n=23)\end{array}$ & 26.187 & 0.079 & 10.940 & NS \\
\hline $\begin{array}{l}\text { Tritherapy }(n=23) \\
\text { vs Monotherapy }(n=5)\end{array}$ & 17.043 & 1.000 & 15.522 & NS \\
\hline $\begin{array}{l}\text { Tritherapy }(n=23) \\
\text { vs Monotherapy }(n=5)\end{array}$ & 9.710 & 1.000 & 6.225 & NS \\
\hline $\begin{array}{l}\text { Monotherapy }(\mathrm{n}=5) \\
\text { vs Bitherapy }(\mathrm{n}=27)\end{array}$ & 7.333 & 1.000 & 9.296 & NS \\
\hline
\end{tabular}

vs: versus; n: number of hospitalized patients with controlled BP; NS: no significant.

Table 6. Comparison of the effect of antihypertensive class combinations on the mean reduction of SBP among hospitalized patients.

\begin{tabular}{lll}
\hline \multicolumn{1}{c}{$\begin{array}{c}\text { Antihypertensive class } \\
\text { combination }\end{array}$} & \multicolumn{2}{c}{ SBP reduction $(\mathrm{mmHg})$} \\
\cline { 2 - 3 } & Mean value \pm SEM & $\mathrm{p}$ \\
\hline $\mathrm{D}+$ CCA $(\mathrm{n}=7)$ & $52.143 \pm 5.759$ & \\
$\mathrm{D}+$ ACEI $(\mathrm{n}=11)$ & $55.000 \pm 7.949$ & \\
$\mathrm{D}+$ ACEI + CCA $(\mathrm{n}=9)$ & $61.111 \pm 30.596$ & 0.121 \\
$\mathrm{D}+$ ACEI + CCA + CAAD $(\mathrm{n}=8)$ & $90.000 \pm 26.186$ & \\
Others $(\mathrm{n}=33)$ & $61.818 \pm 35.747$ & \\
\hline
\end{tabular}

D: diuretic; CCA: calcium channel antagonist; ACEI: angiotensin-converting enzyme inhibitor; CAAD: centrally acting antihypertensive drug; $\mathrm{n}=$ number of hospitalized patients with controlled BP; SEM: standard error of mean.

difference of ranks (Table 7).

Patients placed on combination therapy including at least one diuretic were 56 out of $64(87.50 \%)$. The median value of SBP/DBP lowering was $60.00 / 30.00 \mathrm{mmHg}$ (Table 8).

The molecules and fixe combinations which were preferentially prescribed in decreasing frequency were: furosemide, nicardipine, captopril, $\alpha$ methyldopa, hydrochlorothiazide + captopril, atenolol/indapamide and clonidine.

All antihypertensive regimens were associated with some dietary measures (sodium restriction, reduction of cholesterol and saturated fat intake, weight loss, moderation of alcohol intake, smoking cessation, and physical exercise practice). 
Table 7. Comparison of the effect of antihypertensive class combinations on the mean reduction of DBP among hospitalized patients.

\begin{tabular}{|c|c|c|}
\hline \multirow{2}{*}{$\begin{array}{l}\text { Antihypertensive class } \\
\text { combination prescribed }\end{array}$} & \multicolumn{2}{|c|}{ DBP reduction $(\mathrm{mmHg})$} \\
\hline & $\begin{array}{l}\text { Difference of } \\
\text { ranks }\end{array}$ & p \\
\hline $\begin{array}{l}\mathrm{D}+\mathrm{CCA}+\text { ACEI + CAAD }(\mathrm{n}=8) \\
\text { vs } \mathrm{D}+\mathrm{CCA}(\mathrm{n}=7)\end{array}$ & 38.393 & 0.015 \\
\hline $\begin{array}{l}\mathrm{D}+\mathrm{CCA}+\mathrm{ACEI}+\mathrm{CAAD}(\mathrm{n}=8) \\
\text { vs others }(\mathrm{n}=33)\end{array}$ & 19.129 & 0.334 \\
\hline $\begin{array}{l}\mathrm{D}+\text { CCA + ACEI + CAAD }(\mathrm{n}=8) \\
\text { vs } \mathrm{D}+\text { ACEI }(\mathrm{n}=11)\end{array}$ & 18.523 & 0.789 \\
\hline $\begin{array}{l}\mathrm{D}+\mathrm{CCA}+\text { ACEI + CAAD }(\mathrm{n}=8) \\
\mathrm{vs} \mathrm{D}+\mathrm{CCA}+\text { ACEI }(\mathrm{n}=9)\end{array}$ & 15.694 & 1.000 \\
\hline $\begin{array}{l}\mathrm{D}+\mathrm{CCA}+\mathrm{ACEI}(\mathrm{n}=9) \\
\mathrm{vs} \mathrm{D}+\mathrm{CCA}(\mathrm{n}=7)\end{array}$ & 22.698 & 0.478 \\
\hline $\begin{array}{l}D+\text { CCA + ACEI }(n=9) \\
\text { vs others }(n=33)\end{array}$ & 3.434 & 1.000 \\
\hline $\begin{array}{l}\mathrm{D}+\mathrm{CCA}+\text { ACEI }(\mathrm{n}=9) \\
\text { vs } \mathrm{D}+\text { ACEI }(\mathrm{n}=11)\end{array}$ & 2.828 & 1.000 \\
\hline $\begin{array}{l}\mathrm{D}+\text { ACEI }(\mathrm{n}=11) \\
\mathrm{vs} \mathrm{D}+\mathrm{CCA}(\mathrm{n}=7)\end{array}$ & 19.870 & 0.702 \\
\hline $\begin{array}{l}D+\operatorname{ACEI}(n=11) \\
\text { vs others }(n=33)\end{array}$ & 0.606 & 1.000 \\
\hline $\begin{array}{l}\text { Others }(\mathrm{n}=33) \\
\text { vs } \mathrm{D}+\text { CCA }(\mathrm{n}=7)\end{array}$ & 19.262 & 0.421 \\
\hline
\end{tabular}

D: diuretic; CCA: Calcium channel antagonist; ACEI: angiotensin-converting enzyme inhibitor; CAAD: centrally acting antihypertensive drug; n: number of hospitalized patients with controlled BP.

Table 8. Comparison of the effect of antihypertensive class combinations including at least one diuretic on SBP/DBP control among ambulatory and hospitalized patients.

\begin{tabular}{|c|c|c|c|c|}
\hline \multirow{2}{*}{$\begin{array}{c}\text { Antihypertensive class } \\
\text { combinations including at } \\
\text { least one diuretic }\end{array}$} & \multicolumn{2}{|c|}{$\begin{array}{l}\text { SBP reduction } \\
(\mathrm{mmHg})\end{array}$} & \multicolumn{2}{|c|}{$\begin{array}{l}\text { DBP reduction } \\
\quad(\mathrm{mmHg})\end{array}$} \\
\hline & $\begin{array}{l}\text { Median } \\
\text { value }\end{array}$ & $\mathrm{p}$ & $\begin{array}{l}\text { Median } \\
\text { value }\end{array}$ & $\mathrm{p}$ \\
\hline $\begin{array}{l}\text { Ambulatory patients } \\
\qquad(\mathrm{n}=34)\end{array}$ & 30.000 & & 10.000 & \\
\hline $\begin{array}{l}\text { Hospitalized patients } \\
\qquad(\mathrm{n}=56)\end{array}$ & 60.000 & $<0.001$ & 30.000 & $<0.001$ \\
\hline
\end{tabular}

n: number of ambulatory and hospitalized patients with controlled BP.

\section{Discussion}

Our series is essentially urban and does not pretend by that fact to represent the whole Togolese population.

In our study, men $(57.39 \%)$ seem more affected by HBP than women (43.18\%) with male to female ratio of 1.3:1 while Etuk et al. [16] in Nigeria reported a ratio of 1:1.2. However, the average age of $55.01 \pm 12.55$ years is a bit higher than the one referred to in the study by the previous cited author (52.6 \pm 14.6 years) [16].

Our study showed that, globally, out of 176 patients placed on antihypertensive treatment, the disease was controlled among 112 (63.64\%) patients or $36.36 \%$ of resistance to the treatment. That failure rate is a bit lower if we consider the definition of the resistant or refractory HBP: a HBP is said to be refractory when a treatment including hygieno-dietetic measures and the prescription of a drug combination consisting of at least 3 antihypertensive drugs one of which, an adequate dose of diuretic did not succeed in lowering the SBP and DBP less than 140/90 mmHg [17-19]. In our series, 25 patients out of 72 (34.72\%) have been in that figure case.

These results issued from outpatients and inpatients could not be compared to that from Nigeria which situated the rate of BP control among outpatients at $29.0 \%$ and $30.5 \%[16,20]$ according to two studies.

Regarding the sex factor impact (hormonal and physiopathological differences) on SBP and DBP reduction on antihypertensive treatment, we did not observe any statistically significant difference between mean and median values of both sexes among outpatients $(\mathrm{p}=0.142$ for SBP and $\mathrm{p}=0.922$ for DBP) and inpatients ( $\mathrm{p}=$ 0.647 for SBP and $p=0.711$ for DBP). For lack of data in the literature, our results have not been able to be compared to other studies.

Among patients whose BP was controlled, 38.39\% (n $=43$ ) were placed on ambulatory treatment while $61.61 \%$ ( $n=69$ ) were hospitalized. The comparison of mean median values of SBP/DBP showed a statistically significant difference between treated patients $(p=0.001$ for SBP and $p=0.004$ for DBP). That difference could be explained by the poor adherence to treatment, the non respect of the hygieno-dietetic measures by the patients on ambulatory treatment.

It is generally admitted that the HBP management starts by monotherapy at an efficient dose which is going to be a substitute for combinations which are recommended in recent tendencies as first line treatment [2022]. The bitherapy was at the top of prescriptions having allowed to control the disease in $53.49 \%$ of ambulatory patients against $39.13 \%$ of hospitalized patients. Only hospitalized patients were placed on quadritherapy or $>4$ antihypertensive drugs combination with $20.29 \%$ of BP control. Indeed, the patients were often admitted urgently in the hospital with a severe or complicated HBP or when through a failure stage of monotherapy, bitherapy or tritherapy, hence the necessity to use more than 3 molecules to control BP. That result confirms the one referred to by Etuk et al. [16] who preconized the monotherapy, the tritherapy or the quadritherapy from moderate to severe HBP respectively.

The predominance of the bitherapy suggests that the prescribers were warned of negative impact to use the combinations of several molecules which could induce side-effects and reduce the adherence to treatment [20]. However, our results confirm the literature data which 
referred to numerous clinical trials in which the majority of patients needed a treatment with the combination of several antihypertensive agents [8,23-25].

The treated groups placed on hypertensive regimens (monotherapy, bitherapy and tritherapy) among ambulatory patients were comparable regarding the mean values of SBP reduction $(p=0.295)$ and the median values of DBP reduction $(\mathrm{p}=0.576)$. Whereas, quadritherapy induced a significant lowering of SBP compared to monotherapy $(\mathrm{p}=0.043)$ and bitherapy $(\mathrm{p}=0.004)$ among hospitalized patients. Those results could be explained by a poor adherence of outpatients and a more important resort to quadritherapy in hospitalized patients, whose level of adherence was probably better $(61.61 \%$ of BP control).

The lack of significant difference of tritherapy compared to bitherapy and to monotherapy among the two categories of patients, could also be explained by the poor adherence of patients. As a matter of fact, the combination of various molecules negatively influences patients' adherence and consequently BP control [26]; that could explain this apparent lack of difference between the combinations of two molecules compared to monotherapy and of 3 molecules compared to bitherapy [16] or to monotherapy.

The combinations including D + ACEI, D + CCA, D + ACEI + CCA and monotherapy made of CCA were comparable regarding their effect on SBP/DBP control among ambulatory patients. Those combinations including the quadruple therapy and excluding CCA induced no significant SBP mean reduction while the quadritherapy comprising D + CCA + ACEI + CAAD exerted a significant DBP mean reduction $(p=0.015)$ among hospitalized patients compared to D + CCA-based combination. That finding confirms partially the fact that $\mathrm{D}+$ CCA seem the combination the least synergic on both the SBP and DBP because of its partially additive BP reduction $[27,28]$. That result corroborates those of other authors $[29,30]$ who criticize the synergic effect of that combination. Furthermore, it does not count among the "preferred"[15] combinations including ACEI/antagonist of receptor of angiotensin II (ARA II) + D or ACEI/ARA II + CCA combination [15,23,31]; however, that combination is classified as "acceptable" [15]. Among the two categories of hypertensive patients, D + ACEI-based combination was not superior to D + CCA as a partially additive BP reduction combination [32-34] and CCA as monotherapy, despite the fact that, that combination results in fully additive BP reduction [35-39].

In the present study, the bitherapies including D + ACEI and D + CCA-based combinations were the most frequently prescribed; So the patterns of prescription were in accordance with the European revised directives
[40] which recommend a diuretic and a CCA or a renin angiotensin system antagonist (ACEI or ARA II) or a CCA and a renin angiotensin system antagonist whereas the Joint National Committee (JNC) — 7 of 2003 (USA) usually recommends a diuretic in the strategy associating two antihypertensive drugs [8].

The tritherapy which came to the second position of prescriptions (two folds in hospitalized conditions) was not statistically more efficient than monotherapy or bitherapy on the BP reduction. According to JNC-7, in case of bitherapy inefficiency, the optimization of doses or combination to a supplementary antihypertensive drug is recommended [17]. The European directives of 2009 decreed the following: When a tritherapy is necessary, the most rational combination seems to be an angiotensin system antagonist, a CCA and a diuretic at efficient doses [40]. As a matter of fact, the BP reduction obtained with vessel-dilating agents (CCA and ACEI) always induces secondary salts and water retention; hence the interest to associate the diuretics, even their effectiveness on SBP and DBP reduction is less compared to ACEI [41] or CCA [16,41]. Our results agree with European directive: the D + CCA + ACEI combination including 3 major classes of antihypertensive drugs used at the first intention [42] obtained the prescribers preference (12/35). That combination is particularly beneficial to black hypertensive patients; indeed, it has been shown that, that combination improved the BP control as well as the cardio and reno protection [2,43-46]. However, in England and in other European countries, the renin angiotensin system blockers are not recommended at initial treatment in the black race patients [47].

Diuretics were the most frequently prescribed drugs either as a single agent or as diuretic-diuretic fixe dose combination or as combination therapy with other classes of antihypertensive drugs. The combinations consisting of at least one diuretic controlled the BP in $97.14 \%$ vs $87.50 \%$ for respectively ambulatory and hospitalized patients; such combinations induced a significant BP control among ambulatory patients compared to hospitalized patients ( $p<0.001$ for SBP/DBP). As a matter of fact, the diuretics have an unquestionable interest in oedema and volume overload states. Related to racial factor, our findings corroborate with the data of literature which reported that the diuretics are the most efficient drugs with the vessel-dilating agents such as CCA in the black race patients (Africans, Americans, Sub Saharan Africans) $[48,49]$; In accordance with these data, the two first favorite molecules or fixe combinations prescribed in the present study were: hydrochlorothiazide + captopril and nicardipine for outpatients; furosemide and nicardipine for inpatients. But the works of Etuk et al. [16] in Nigeria showed the superiority of CCA on the diuretics in mo- 
notherapy.

All the combinations of quadritherapy used consisted of a diuretic. According to Achard et al. [29], the resort to quadritherapy supposes that the prescriber kept away all the etiology including those of secondary HBP. In that case, the therapeutic procedure will be guided by the analysis of the pressure mechanisms responsible for the resistance to treatment: systolic output, peripheral resistance, sodium concentration, catecholamines activity, renin and aldosterone activity. The same author appends that in principle, despite that analysis, empiricism sometimes remains the single recourse. That empiricism coupled with the difficulty in the management of HBP has been emphasized by other authors: The HBP control remains problematic despite the existence of algorithms allowing to predict the patients' individual response to different groups of antihypertensive drugs [50]; the variability in patients' individual responses to different groups of antihypertensive drugs [50]; the therapeutic inertia [8]; the compensatory responses to antihypertensive treatment [15]; the non respect sometimes in the implementation of JNC 7's recommendations [13,51]. Furthermore, the high and more and more increasing number of hypertensive patients despite the enormous progress in term of HBP treatment, remains a paradox [52].

In conclusion, the results of our study agree with the data of the literature; as the matter of fact, the diuretics, the calcium channel antagonists and the angiotensin converting enzyme inhibitors constitute the 3 groups of the first line antihypertensive drugs in the treatment of essential HBP in our context (patient of black race, ambulatory and hospitalized conditions). The tree pharmacological groups were used in monotherapy, but often in combination with 1, 2, 3 even 4 antihypertensive drugs belonging to other pharmacological groups. However, the D + CCA combination which came to the second position of prescriptions of bitherapy seemed the least synergic. That finding must be taken into account by prescribers. The strategy combining 4 antihypertensive drugs (D + CCA + ACEI + CAAD) used for inpatients reduced significantly the mean DBP compared to D + CCA-based combination. The present study allowed thus to make available important pre-requisites for further additional investigations in order to identify the combinations that is most likely to be beneficial to majority of hypertensive patients.

\section{REFERENCES}

[1] A. A. Lopes, "Hypertension in Black People: Pathophysiology and Therapeutic Aspects. Journal of Human Hypertension, Vol. 16, No. 1, 2002, pp. 11-12. doi:10.1038/sj.jhh.1001333
[2] J. G. Douglas and L. Agodoa, “ACE Inhibition Is Effective and Renoprotective in Hypertensive Nephrosclerosis: The African American Study of Kidney Disease and Hypertension (AASK) Trial,” Kidney International Supplements, Vol. 63, Suppl. 83, 2003, pp. 74-76.

[3] B. L. Salako, F. A. Ajose and E. Lawani, "Blood Pressure Control in a Population Where Antihypertensives Are Given Free,” East African Medical Journal, Vol. 80, No. 10, 2003, pp. 529-531.

[4] S. A. Isezuo and C. H. Njoku, "Blood Pressure Control among Antihypertensives Managed in a Specialized Health Care Sitting in Nigeria," African Journal of Medicine \& Medical Sciences, Vol. 32, 2003, pp. 65-70.

[5] S. A. Isezuo and T. C. Opera, "Hypertension Awareness among Nigerian Hypertensives in a Nigerian Tertiary Health Institution,” Sahel Medical Journal, Vol. 3, No. 2, 2000, pp. 93-97.

[6] D. J. Hyman and V. N. Pavlik, "Characteristics of Patients with Uncontrolled Hypertension in the United States," The New England Journal of Medicine, Vol. 345, No. 7, 2001, pp. 479-486. doi:10.1056/NEJMoa010273

[7] X. S. Ren, L. E. Kazis, A. Lee, H. Zhang and D. R. Miller, "Identifying Patient and Physician Characteristics That Effect Compliance with Antihypertensive Medications," Journal of Clinical Pharmacy and Therapeutics, Vol. 27, No. 1, 2002, pp. 47-56. doi:10.1046/j.1365-2710.2002.00387.x

[8] R. Düsing, "Optimizing Blood Pressure Control through the Use of Fixed Combinations," Vascular Health and Risk Management, Vol. 6, 2010, pp. 321-325.

[9] F. Damorou, E. Togbossi, F. Pessinaba and B. Soussou, Epidemiology and Diagnostic Circumstances of Arterial Hypertension in the Hospital Environment in Kpalime (Second Largest City in Togo)," Mali Medical, Vol. 23, No. 4, 2008, pp. 17-20.

[10] F. Damorou, F. Pessinaba, T. Tcherou, K. Yayehd, S. M. Ndassa and B. Soussou, “Arterial Hypertension in Black Subjects over 50 Years of Age in Lomé: Epidemiological Aspects and Evaluation of Cardiovascular Risk (Prospective and Longitudinal Study of 1485 Patients)," Annales de Cardiologie et d'Angéiologie (Paris), Vol. 60, No. 2, 2011, pp. 61-66.

[11] C. P. Page, M. J. Curtis, M. J. Walker, M. C. Sutter and B. B. Hoffman, "Integrated Pharmacology," 1st Edition, DeBoeck Université, Paris, 1999.

[12] E. Poluzzi, P. Strahinja, A. Vargiu, G. Chiabrando, M. C. Silvani, D. Motola, G. S. Cellini, A. Vaccheri, F. de Ponti and N. Montanaro, "Initial Treatment of Hypertension and Adherence to Therapy in General Practice in Italy," European Journal of Clinical Pharmacology, Vol. 61, No. 8, 2005, pp. 603-609. doi:10.1007/s00228-005-0957-y

[13] B. A. Staffileno, “Treating Hypertension with Cardioprotective Therapies, the Role of ACE Inhibitors, ARBs, and Beta-Blockers,” Journal of Cardiovascular Nursing, Vol. 20, No. 5, 2005, pp. 354-364.

[14] K. H. Rahn, "Recent Intervention Studies with Antihypertensive Drugs and Their Influence on Guidelines,” Medi- 
zinische Klinik (Munich), Vol. 98, No. 12, 2003, pp. 771775. doi:10.1007/s00063-003-1323-4

[15] A. H. Gradman, J. N. Basile, B. L. Carter and G. L. Bakris, "Combination Therapy in Hypertension," The Journal of Clinical Hypertension, Vol. 13, No. 3, 2011, pp. 146-154. doi:10.1111/j.1751-7176.2010.00397.x

[16] E. Etuk, S. A. Isezuo, A. Chika, J. Akuche and M. Ali, "Prescription Pattern of Anti-Hypertensive Drugs in a Tertiary Health Institution in Nigeria,” Annals of African Medicine, Vol. 7, No. 3, 2008, pp. 128-132. doi:10.4103/1596-3519.55665

[17] A. V. Chobanian, G. L. Bakris, H. R. Black, W. C. Cushman, L. A. Green, J. L. Izzo Jr., D. W. Jones, B. J. Materson, S. Oparil, J. T. Wright Jr., E. J. Roccella and The National High Blood Pressure Education Program Coordinating Committee, "Seventh Report of the Joint National Committee on Prevention, Detection, Evaluation and Treatment of High Blood Pressure," Journal of the American Medical Association, Vol. 289, No. 19, 2003, pp. 2560-2572. doi:10.1001/jama.289.19.2560

[18] J. F. Setaro and H. R. Black, "Refractory Hypertension," New England Journal of Medicine, Vol. 327, No. 8, 1992, pp. 543-547. doi:10.1056/NEJM199208203270808

[19] The Task Force for the Management of Arterial Hypertension of the European Society of Hypertension (ESH) ESH and ESC and of the European Society of Cardiology. Guidelines for the Management of Arterial Hypertension. Journal of Hypertension, Vol. 25, No. 6, 2007, pp. 11051187. doi:10.1097/HJH.0b013e3281fc975a

[20] K. B. Yusuff and O. Balogun, "Physicians Prescribing of Antihypertensive Combinations in Tertiary Care Setting in Southwestern Nigeria,” Journal of Pharmaceutical Sciences, Vol. 8, No. 2, 2005, pp. 235-242.

[21] I. Gavras and T. Tsenthal, "Combination Therapy as FirstLine Treatment for Hypertension,” Current Hypertension Reports, Vol. 6, No. 4, 2004, pp. 267-272. doi:10.1007/s11906-004-0020-X

[22] J. M. Neutel, "The Role of Combination Therapy in the Management of Hypertension,” Nephrology Dialysis Transplantation, Vol. 21, No. 6, 2006, pp. 1469-1473. doi:10.1093/ndt/gfk064

[23] A. V. Chobanian, G. L. Bakris, H. R. Black, W. C. Cushman, L. A. Green, J. L. Izzo Jr., D. W. Jones, B. J. Materson, S. Oparil, J. T. Wright Jr. and E. J. Roccella, "Seventh Report of the Joint National Committee on Prevention, Detection, Evaluation and Treatment of High Blood Pressure,” Hypertension, Vol. 42, No. 6, 2003, pp. 1206-1252. doi:10.1161/01.HYP.0000107251.49515.c2

[24] L. Hanson, A. Zanchetti, S. G. Carruthers, B. Dahlöf, D. Elmfeldt, S. Julius, J. Ménard, K. H. Rahn, H. Wedel and S. Westerling, "Effects of Intensive Blood Pressure Lowering and Low-Dose Aspirin in Patients with Hypertension: Principal Results of the Hypertension Optimal Treatment (HOT) Randomized Trial,” Lancet, Vol. 351, No. 9118, 1998, pp. 1755-1762. doi:10.1016/S0140-6736(98)04311-6

[25] J. Chalmer, "The ABCD of Antihypertensive Therapy?" Journal of Hypertension, Vol. 20, No. 4, 2002, pp. 615-

\section{6. doi:10.1097/00004872-200204000-00016}

[26] J. G. Douglas, G. L. Bakris, M. Epstein, K. C. Ferdinand, C. Ferrario, J. M. Flack, K. A. Jamerson, W. E. Jones, J. Haywood, R. Maxey, E. O. Ofili, E. Saunders, E. L. Schiffrin, D. A. Sica, J. R. Sowers and D. G. Vidt, "Management of High Blood Pressure in African Americans: Consensus Statement of the Hypertension in African Americans. Working Group of the International Society on Hypertension on Blacks,” Archives of Internal Medicine, Vol. 163, No. 5, 2003, pp. 525-541. doi:10.1001/archinte.163.5.525

[27] A. Salvetti, A. Magagna, P. Innocenti, F. Ponzanelli, A. Cagianelli, M. Cipriani, E. Gandolfi, C. Del Prato, A. M. Ballestra, P. Saba, F. Giuntoli, G. Panebianco and S. Amigoni, "The Combination of Chlorthalidone with Nifedipine Does Not Exert an Additive Antihypertensive Effect in Essential Hypertensives: A Crossover Multicenter Study," Journal of Cardiovascular Pharmacology, Vol. 17, No. 2, 1991, pp. 332-335. doi:10.1097/00005344-199102000-00021

[28] M. R. Weir, M. A. Weber, H. A. Punzi, H. M. Serfer, S. Rosenblatt and W. J. Cady, "A Dose Escalation Trial Comparing the Combination of Diltiazem SR and Hydrochlorothiazide with the Monotherapies in Patients with Essential Hypertension,” Journal of Human Hypertension, Vol. 6, No. 2, 1992, pp. 133-138.

[29] J. M. Achard and A. Fournier, "Facteurs de Résistance au Traitement d'une HTA,” Revue du Praticien, Vol. 14, 1993, pp. 1813-1819.

[30] C. Thuillez, "Inhibiteurs Calciques," Revue du Praticien, Vol. 9, 1993, pp. 1163-1165.

[31] A. H. Gradman, J. N. Basile, B. L. Carter, G. L. Brakis, B. J. Materson, H. R. Black, J. L. Izzo Jr., S. Oparil and M. A. Weber, "Combination Therapy in Hypertension," Journal of the American Society of Hypertension, Vol. 4, No. 2, 2010, pp. 90-98. doi:10.1016/j.jash.2010.03.001

[32] W. H. Frishman, C. V. S. Ram, F. G. McMahon, S. G. Chrysant, A. Graff, J. W. Kupiec and H. Hsu, "Comparison of Amlodipine and Benazepril Monotherapy to Amlodipine plus Benazepril in Patients with Systemic Hypertension: A Randomized, Double-Blind, PlaceboControlled, Parallel-Group Study," The Journal of Clinical Pharmacology, Vol. 35, No. 11, 1995, pp. 10601066.

[33] T. Philipp, T. R. Smith, R. Glazer, M. Wernsing, J. Yen, J. Jin, H. Schneider and R. Pospiech, "Two Multicenter, 8Week, Randomized, Double-Blind, Placebo-Controlled, Parallel-Group Studies Evaluating the Efficacy and Tolerability of Amlodipine and Valsartan in Combination and as Monotherapy in Adult Patients with Mild to Moderate Essential Hypertension," Clinical Therapeutics, Vol. 29, No. 4, 2007, pp. 563-580. doi:10.1016/j.clinthera.2007.03.018

[34] S. G. Chrysant, M. Melino, S. Karki, J. Lee and R. Heyrman, "The Combination of Olmesartan Medoxomil and Amlodipine Besylate in Controlling High Blood Pressure: $\mathrm{COACH}$, a Randomized, Double-Blind, Controlled, 8Week Factorial Efficacy and Safety Study,” Clinical The- 
rapeutics, Vol. 30, No. 4, 2008, pp. 587-604.

doi:10.1016/j.clinthera.2008.04.002

[35] S. G. Chrysant, “Antihypertensive Effectiveness of LowDose Lisinopril Hydrochlorothiazide Combination,” Archives of Internal Medicine, Vol. 154, No. 7, 1994, pp. 737-743. doi:10.1001/archinte.154.7.737

[36] S. G. Chrysant, T. Fagan, R. Glazer and A. Kriegman, "Effects of Benazepril and Hydrochlorothiazide, Given Alone and in Low- and High-Dose Combinations, on Blood Pressure in Patients with Hypertension," The Annals of Family Medicine, Vol. 5, No. 1, 1996, pp. 17-24. doi:10.1001/archfami.5.1.17

[37] J. Pool, W. C. Cushman, R. K. Saini, C. E. Nwachuku and J. P. Battikha, "Use of the Factorial Design and Quadratic Response Surface Models to Evaluate the Fosinopril and Hydrochlorothiazide Combination Therapy in Hypertension,” American Journal of Hypertension, Vol. 10, No. 1, 1997, pp. 117-123. doi:10.1016/S0895-7061(96)00323-8

[38] A. H. Gradman and R. Kad, "Renin Inhibition in Hypertension," Journal of the American College of Cardiology, Vol. 51, No. 5, 2008, pp. 519-528. doi:10.1016/j.jacc.2007.10.027

[39] J. H. Mackay, K. E. Arcuri, A. I. Goldberg, S. M. Snapinn and C. S. Sweet, "Losartan and Low-Dose Hydrochlorothiazide in Patients with Essential Hypertension," Archives of Internal Medicine, Vol. 156, No. 3, 1996, pp. 278-285. doi:10.1001/archinte.1996.00440030072009

[40] G. Mancia, S. Laurent, E. Agabiti-Rosei, E. Ambrosioni, M. Burnier, M. J. Caulfield, R. Cifkova, D. Clément, A. Coca, A. Dominiczak, S. Erdine, R. Fagard, C. Farsang, G. Grassi, H. Haller, A. Heagerty, S. E. Kjeldsen, W. Kiowski, J. M. Mallion, A. Manolis, K. Narkiewicz, P. Nilsson, M. H. Olsen, K. H. Rahn, J. Redon, J. Rodicio, L. Ruilope, R. E. Schmieder, H. A. Struijker-Boudier, P. A. van Zwieten, M. Viigimaa and A. Zanchetti, "Reappraisal of European Guidelines on Hypertension Management: An European Society of Hypertension Task Force Document,” Journal of Hypertension, Vol. 27, No. 11, 2009, pp. 2121-2158. doi:10.1097/HJH.0b013e328333146d

[41] M. Veronesi, A. F. G. Cicero, M. G. Prandin, A. Dormi, E. Cosentino, E. Strocchi and C. Borghi, "A Prospective Evaluation of Persistence on Antihypertensive Treatment with Different Antihypertensive Drugs in Clinical Practice," Vascular Health and Risk Management, Vol. 3, No. 6, 2007, pp. 1000-1005.

[42] J. T. Wright Jr., J. K. Dunn, J. A. Cutler, B. R. Davis, W. C. Cushman, C. E. Ford, L. J. Haywood, F. H. Leenen, K. L. Margolis, V. Papademetriou, J. L. Probstfield, P. K. Whelton and G. B. Habib, "Outcomes in Hypertensive Black and Nonblack Patients Treated with Chlorthalidone, Amlodipine, and Lisinopril," Journal of the American Medical Association, Vol. 293, No. 13, 2005, pp. 1595-
1608. doi:10.1001/jama.293.13.1595

[43] D. E. Bild, D. A. Bluemke, G. L. Burke, R. Detrano, A. V. D. Roux, A. R. Folsom, P. Greenland, D. R. Jacob Jr., R. Kronmal, K. Liu, J. C. Nelson, D. O’Leary, M. F. Saad, S. Shea, M. Szklo, R. P. Tracy, "Multi-Ethnic Study of Atherosclerosis, Objective and Design," American Journal of Epidemiology, Vol. 156, No. 9, 2002, pp. 871-881. doi:10.1093/aje/kwf113

[44] A. Fenves and C. V. Ram, "Are Angiotensins Converting Enzyme Inhibitors and Angiotensin Receptor Blokers Becoming the Treatment of Choice in African-American?” Current Hypertension Reports, Vol. 4, No. 4, 2002, pp. 286-289. doi:10.1007/s11906-996-0006-y

[45] M. Rahman, "Initial Findings of the AASK, African Americans Kidney Benefit from an ACE Inhibitor,” Cleveland Clinic Journal of Medicine, Vol. 70, No. 4, 2003, pp. 304-305. doi:10.3949/ccjm.70.4.304

[46] L. Hanson, L. H. Lindholm, L. Niskanen, J. Lanke, T. Hedner, A. Niklason, K. Luomanmäki, B. Dahlöf, U. de Faire, C. Mörlin, B. E. Karlberg, P. O. Wester and J. E. Björck, "Effect of Angiotensin Converting Enzyme Inhibition Compared with Conventional Morbidity and Mortality in Hypertension: The Captopril Prevention Project (CAPPP) Randomized Trial,” Lancet, Vol. 353, No. 9153, 1999, pp. 611-616. doi:10.1016/S0140-6736(98)05012-0

[47] J. L. Izzo Jr. and A. S. Zion, “Combined Aliskiren-Amlodipine Treatment for Hypertension in African Americans Clinical Science and Management Issues,” Therapeutic Advances in Cardiovascular Disease, Vol. 5, No. 3, 2011, pp. 169-1725. doi:10.1177/1753944711409615

[48] E. Saunders, "Hypertension in Blacks," Primary Care, Vol. 18, 1881, pp. 607-622.

[49] L. A. Salako, "Hypertension in Africa and Effectiveness of Its Management with Various Classes of Antihypertensive Drugs and in Different Socio-Economic and Cultural Environments," Clinical and Experimental Hypertension, Vol. 15, No. 6, 1993, pp. 997-1004. doi:10.3109/10641969309037087

[50] L. Welsh and A. Ferro, "Drug Treatment of Essential Hypertension: The Case for Initial Combination Therapy," International Journal of Clinical Practice, Vol. 58, No. 10, 2004, pp. 956-963. doi:10.1111/j.1368-5031.2004.00392.x

[51] S. A. Revaz, A. Morabia, C. Goehring and H. Stalder, "Evaluation of Drug Prescription in the Primary Care Clinic in Geneva in 1997," Schweiz Med Wochenschr, Vol. 129, No. 49, 1999, pp. 1935-1937.

[52] A. V. Chobanian, "The Hypertension Paradox-More Uncontrolled Disease despite Improved Therapy,” The New England Journal of Medicine, Vol. 361, No. 9, 2009, pp. 878-887. doi:10.1056/NEJMsa0903829 


\section{Abreviations}

HBP: High blood pressure;

BP: Blood pressure;

SBP: Systolic blood pressure;

DBP: Diastolic blood pressure;

D: Diuretic;

CCA: Calcium channel antagonist;
ACEI: Angiotensin-converting enzyme inhibitor; CAAD: Centrally acting antihypertensive drug; ARA II: Antagonist of receptor of angiotensin II; $\mathrm{n}=$ Number of patients treated; SEM: Standard error of mean; WHO: World Health Organisation, JNC: Joint National Committee. 